\title{
ANALISIS PERSAINGAN USAHA PEDAGANG MUSIMAN DI NGEBEL PONOROGO DITINJAU DARI PERSPEKTIF ETIKA BISNIS ISLAM
}

\author{
Siti Hofifah* \\ *Fakultas Ekonomi dan Bisnis Islam, Institut Agama Islam Negeri Ponorogo \\ Jl. Puspita Jaya, Krajan Pintu, Jenangan Ponorogo Jawa Timur 63492 Indonesia \\ e-mail : sitihoffifah25@gmail.com
}

\begin{abstract}
Abstrak: Usaha merupakan aktivitas ekonomi yang memiliki peranan penting dalam memenuhi kebutuhan manusia. Kegiatan usaha tersebut meliputi menjadi produsen, konsumen maupun perantara. Salah satunya berupa perdagangan. Seiring perkembangan zaman kegiatan bisnis khususnya perdagangan semakin meningkat. Tidak dipungkiri persaingan dalam dunia bisnis juga ikut meningkat. Dalam hal ini mengakibatkan pelaku bisnis harus membuat strategistrategi yang tepat dalam melakukan perdagangan produknya dan agar dapat memaksimalkan persaingan untuk mendapatkan keuntungan atau laba. Namun dalam hal ini dengan banyaknya persaingan banyak sebagian pedagang yang tidak menghiraukan etika bisnis Islam demi memperoleh keuntungan yang tinggi. Tujuan dalam penelitian ini adalah untuk mengetahui persaingan usaha pedagang musiman di daerah Ngebel Ponorogo dan untuk mengetahui tinjauan perspektif etika bisnis islam terhadap perilaku para pedagang musiman di daerah tersebut. Berdasarkan hasil analisis penelitian ini dapat disimpulkan bahwa sebagian pedagang tidak menggunakan etika bisnis Islam karena banyaknya persaingan dan juga untuk tujuan memperoleh keuntungan sebanyak-banyaknya demi kebutuhan perekonomiannya. Diharapkan melalui hasil penelitian ini dapat dijadikan masukan bagi para pedagang musiman untuk menerapkan etika bisnis Islam dalam proses perdagangannya.
\end{abstract}

Kata Kunci: Persaingan usaha, Pedagang, Etika Bisnis Islam. 


\section{PENDAHULUAN}

Di era globalisasi sekarang ini, usaha merupakan bagian dari kegiatan ekonomi dan memiliki peranan yang sangat penting dalam memenuhi kebutuhan manusia. Kegiatan usaha ini mempengaruhi tingkat kehidupan semua manusia. Kegiatan usaha tersebut meliputi menjadi produsen, konsumen maupun perantara.

Dengan seiring perkembangan zaman tersebut kegiatan bisnis khususnya perdagangan semakin meningkat. Persaingan dalam dunia bisnis pun juga ikut meningkat. Sehingga dalam hal ini pelaku bisnis atau usaha juga perlu membuat strategi-strategi yang tepat dalam melakukan perdagangan produknya serta memenangkan persaingan untuk memaksimalkan pendapatan keuntungan atau laba.

Persaingan bisnis atau usaha adalah perseteruan rivalitas antara pelaku bisnis yang secara independen berusaha mendapatkan konsumen dengan menawarkan harga yang baik dengan kualitas barang atau jasa yang baik juga (Mujahidin, 2007:27).

Sedangkan persaingan bisnis dalam Islam ini merupakan kompetisi yang diperbolehkan, asalkan persaingan usaha itu dilaksanakan secara sehat, akan tetapi apabila persaingan usaha yang dilaksanakan itu bersifat monopolistik dalam rangka mengambil keuntungan, maka ekonomi Islam melarangnya (Susanto et.al, 2019:100)

Konsep persaingan bisnis yang telah dijelaskan dalam Al-Qur'an adalah sebuah konsep persaingan yang mengharuskan para pebisnis bersaing secara sportif dengan memberikan kontribusi yang baik dari bisnisnya dan tidak untuk menjatuhkan pebisnis lainnya.
Pada dasarnya persaingan bisnis menurut syariat Islam ialah dalam bersaing haruslah secara sehat, jujur, berperilaku baik, simpatik, adil serta menjalin silaturahmi, agar dapat mempererat ikatan persaudaraan. Jadi dalam melakukan persaingan pada setiap individunya ini terdapat dalam kaidahkaidah Islam dan Akhlak. Allah SWT berfirman dalam surat Al-Qashash ayat 77

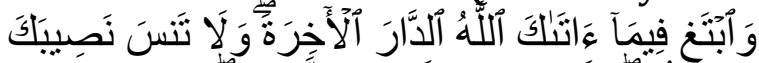

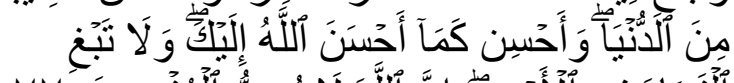

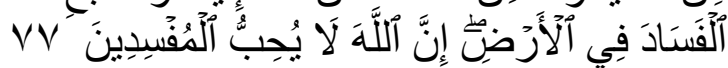
Artinya:" Dan carilah pada apa yang telah dianugrahkan Allah kepadamu (kebahagiaan) negeri akhirat, dan janganlah kamu melupakan bahagiamu dari (kenikmatan) duniawi dan berbuat baiklah (kepada orang lain) sebagaimana Allah telah berbuat baik, kepadamu, dan janganlah kamu berbuat kerusakan di (muka) bumi. Sesungguhnya Allah tidak menyukai orang-orang yang berbuat kerusakan (Q.S. Al-Qasash:77)

Adapun maksud dari ayat di atas bahwasannya dalam melakukan sesuatu hak kepada sesama manusia harus dengan baik jangan berbuat yang tidak baik agar Allah memberikan nikmat dan kebahagiaan terhadap hamba-Nya. Selain itu didalam Al-Qur'an juga tidak memperbolehkan melakukan persaingan yang bertujuan untuk memperoleh keuntungan sebanyak- banyaknya dengan tidak menghiraukan nilai-nilai yang telah diajarkan Islam.

$$
\text { Brian Indrajaya }
$$
menyebutkan bahwa Persaingan usaha antar pedagang sembako di Pasar Kliwon Karanglewas sebagian besar aktivitas persaingan usaha pedagang sembako sesuai dengan etika bisnis Islam, namun dari segi harga terdapat beberapa pedagang yang dalam 
prakteknya bertentangan dengan bisnis Islam.

Sedangkan Putri Witha Stefhani (2009) menyebutkan bahwa persaingan usaha dalam perspektik etika bisnis Islam pada pedagang sayur keliling dan warung saru di desa Banjarrejo Lampung Timur belum sesuai dengan etika bisnis Islam, karena keterbatasan pengetahuan yang dimiliki, sehingga mereka mengetahui tentang persaingan usaha yaitu hanya menerapkan strategi yang dapat menguntungkan sebanyakbanyaknya tanpa mengikuti ketentuan dalam hukum Islam.

$$
\text { Dengan meningkatnya }
$$

persaingan saat ini, banyak sebagian pedagang yang tidak menghiraukan etika bisnis Islam demi memperoleh keuntungan yang tinggi. Masalah seperti ini bisa ditemukan di lingkungan pedagang musiman daerah Ngebel Ponorogo. Ada sebagian pedagang yang melakukan penyimpangan dalam penjualannya seperti, mengurangi takaran, pengoplosan barang kualitas bagus dengan yang buruk serta timbangan yang kurang pas.

Penulis memilih persaingan dalam perspektif etika bisnis karena dilihat dari persaingan pedagang musiman di desa Ngebel Ponorogo ada sebagian pelaku dagang menggunakan cara berjualan yang bertentangan dengan etika bisnis Islam. Seperti sebagian pedagang yang mengurangi ukuran, takaran maupun dalam penimbangannya tidak sesuai dengan aturan. Padahal hal ini sudah jelas dilarang dalam Islam seperti yang telah dicantumkan dalam Al-Qur'an surah AlMuthafifin (83): ayat 1-3:

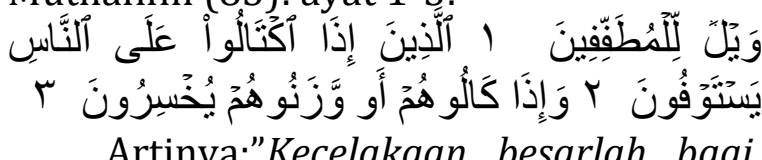

Artinya:"Kecelakaan besarlah bagi orang-orang yang curang, (yaitu) orangorang yang apabila menerima takaran dari orang lain mereka minta dipenuhi, dan apabila mereka menakar atau menimbang untuk orang lain, mereka mengurangi."

Selain itu terkadang pedagang menjual barangnya dengan harga mahal dan mengaku kualitasnya bagus. Padahal kualitasnya itu tidak sesuai yang dibicarakan sebelumnya. Namun dalam hal ini pelayanan yang diterapkan bagus. Karena semata-mata untuk menarik pelanggan agar mau membeli dagangannya.

\section{TINJAUAN PUSTAKA \\ Persaingan Usaha}

Persaingan berasal dari kata dasar "saing" yang artinya berlomba atau mengatasi, dahulu mendahului, dengan kata lain yaitu usaha untuk memperhatikan keunggulan masingmasing yang dilakukan perseorangan atau badan hukum dalam bidang perdagangan, produksi, maupun pertahanan (Andini dan Aditya, 2002:382).

Jadi maksud dari persaingan ini merupakan bersaingnya para pedagang yang sama-sama berusaha atau ingin mendapatkan keuntungan, pangsa pasar dan juga jumlah penjualan. Para pedagang ini biasanya melakukan persaingan dengan membedakan harga, kualitas produk, distribusi maupun mempromosikannya.

Penjelasan tentang persaingan usaha dapat ditemui dalam UndangUndang No. 5 tahun 1999 tentang larangan praktek Monopoli dan persaingan tidak sehat. Secara umum, persaingan bisnis adalah perseteruan atau rivalitas antara pelaku bisnis yang secara independen berusaha mendapatkan konsumen dengan menawarkan harga yang baik dengan 
kualitas barang atau jasa yang baik pula (Undang-undang No.5 Tahun 1999).

Persaingan usaha ini

dikategorikan menjadi 2 yaitu:

a. Persaingan usaha sehat (Perfec Compotition) ini memiliki ciri-ciri yaitu:

1. Menjamin persaingan di pasar yang inheren dengan pencapaian efisiensi ekonomi di semua bidang kegiatan usaha dan perdagangan.

2. Menjamin semua kesejahteraan konsumen serta melindungi kepentingan konsumen.

3. Membuka peluang pasar yang seluas-luasnya dan menjaga agar tidak terjadi konsentrasi kekuatan ekonomi pada kelompok tertentu.

b. Persaingan usaha tidak sehat (Unperfect Competition) ini merupakan persaingan yang mencegah calon pesaing atau menyingkirkan pesaing dengan cara-cara yang curang. Adapun tindakan-tindakan yang dilakukan dalam persaingan usaha tidak sehat yaitu:

1. Monopoli adalah suatu pasar disebut monopoli apabila pasar tersebut terdiri atas satu produsen dengan banyak pembeli dan terlindungi dari persaingan, pasar yang bersifat monopoli umumnya menghasilkan kuantitas produk yang lebih sedikit sehingga masyarakat membayar dengan harga yang lebih tinggi.
2. Kartel adalah bangunan dari perusahaan yang sejenis yang secara terbuka sepakat untuk mengatur kegiatannya.

3. Dominan Firm adalah pasar yang jumlah produsen yang banyak tidak indentik bahwa pasar tersebut bersaing sempurna, jumlah perusahaan tidak akan berarti apabila dalam pasar yang bersangkutan terdapat dominan firm atau posisi dominan.

4. Penetapan harga

Bagi pelaku usaha dilarang membuat perjanjian dengan pelaku usaha pesaingnya untuk menetapkan harga atas suatu barang dan jasa atau jasa yang harus dibayar oleh konsumen atau pelanggan pada pasar bersangkutan yang sama.

\section{Pedagang Musiman}

Pedagang adalah orang yang melakukan perdagangan, memperjual belikan barang yang tidak diproduksi sendiri, untuk memperoleh keuntungan (Sujatmiko, 2014:231). Sedangkan pedagang musiman adalah orang yang melakukan transaksi jual beli atau melakukan pertukaran baik berupa barang dan jasa yang dilakukan pada waktu atau tempat tertentu. Pedagang ini merupakan orang yang melakukan kegiatan perdagangan setiap hari untuk memenuhi kebutuhan perekonomiannya.

\section{Etika Bisnis Islam}

Bisnis merupakan suatu aktivitas yang dilakukan oleh seseorang atau sekelompok orang untuk menyediakan 
barang dan jasa dengan tujuan memperoleh keuntungan. Sedangkan etika adalah komponen pendukung para pelaku bisnis atau usaha terutama dalam hal kepribadian, tindakan dan perilakunya (Zamzan dan Havis Aravik, 2020:1). Jadi etika bisnis merupakan aturan-aturan main yang berhubungan erat dengan norma-norma dan prinsipprinsip umum yang berlaku di dalam masyarakat yang bertujuan untuk memberikan rasa aman dan nyaman bagi pihak-pihak yang melakukan aktivitas bisnis yang didalamnya terdapat aspek hukum, kepemilikan, pengelolaan dan pendistribusian harta. Jadi dalam etika bisnis ini berhubungan erat dengan stakeholder maupun konsumen.

Bisnis Islami adalah upaya pengembangan modal untuk kebutuhan hidup yang dilakukan dengan memperhatikan etika islam. Bisnis Islami juga dapat diartikan sebagai serangkaian aktivitas bisnis dalam berbagai bentuk yang tidak dibatasi jumlah kepemilikan barang maupun jasa termasuk profit. Namun dibatasi dalam cara memperolehnya dan pendayagunaan hartanya karena aturan halal dan haram. Sesuai dalam firman Allah SWT dalam Q.S Al-Baqarah 188:

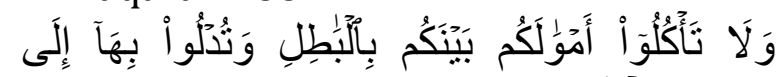

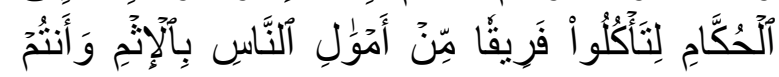

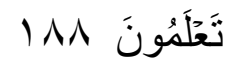

Artinya: "Dan janganlah kamu makan harta di antara kamu dengan jalan yang batil, dan (janganlah) kamu menyuap dengan harta itu kepada para hakim, dengan maksud agar kamu dapat memakan sebagian harta orang lain itu dengan jalan dosa, padahal kamu mengetahui (Qs. Al-Baqarah:188).

Maksud dari ayat tersebut sudah jelas bahwa kita sebagai umat muslim harus memperoleh maupun menggunakan harta dari perolehan yang halal dan tidak ada unsur riba. Sedangkan etika bisnis Islam ini merupakan suatu aturan, norma-norma dan prinsip yang dilakukan masyarakat yang mengharuskan sesuai dengan apa yang telah ditetapkan oleh ajaran Islam.

\section{Fungsi Etika Bisnis Islam}

Fungsi bisnis pada intinya mempersiapkan segala produk yang dibutuhkan oleh masyarakat serta mendesain sesuatu yang bersifat biasa saja atau bernilai kecil menjadi sesuatu yang luar biasa atau bernilai besar. Dalam konteks bisnis secara islami haruslah mengedepankan etika bisnis Islam "akhlak" karena akhlak adalah modal utama sebagaimana sabda Nabi Muhammad SAW:

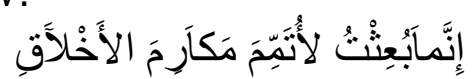

Artinya: "sesungguhnya aku diatas hanya untuk menyempurnakan kesalehan akhlak" (HR. Al-Baihaqi).

Rasulullah Saw adalah sosok atau figur yang kita teladani, artinya dalam konteks menjalankan bisnis Islam Mengacu kepada beliau "Nabi Muhammad $S A W^{\prime \prime}$ agar dalam berbisnis mendapatkan keberkahan insyaallah selamat dunia dan akhirat.

Fungsi khusus etika bisnis Islam terdiri dari beberapa komponen yaitu: 
a. Etika bisnis berupaya mencari cara untuk menyelaraskan dan menyerasikan berbagai kepentingan dalam dunia bisnis.

b. Etika bisnis juga mempunyai peran untuk senantiasa melakukan perubahan kesadaran bagi masyarakat tentang bisnis terutama bisnis Islami. Caranya dengan memberikan suatu pemahaman serta cara pandang baru tentang bisnis dengan menggunakan landasan nilai-nilai moralitas dan spiritualitas.

c. Etika bisnis terutama etika bisnis Islam juga bisa berperan memberikan satu solusi terhadap berbagai persoalan bisnis modern ini yang kian jauh dari nilai-nilai etika. Dalam arti bahwa bisnis yang beretika harus benar-benar merujuk pada sumber utamanya yaiu AlQur'an dan Sunnah.

\section{Prinsip-Prinsip Etika Bisnis Islam}

Adapun prinsip-prinsip etika bisnis Islam yang menjadi dasar adalah sifat-sifat Rasulullah SAW yang terdiri dari:

a. Shidiq.

Shidiq artinya benar. Dalam konteks menjalankan bisnis Islam tidak hanya benar dalam perkataan atau ucapan namun juga dituntut benar secara perbuatan (Aprianto, 2020:12-14). Allah SWT berfirman dalam surah An-Najm ayat 4:

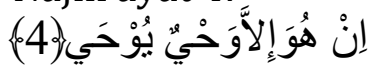

Artinya:" Ucapannya itu tiada lain hanyalah wahyu yang diwahyukan (kepadanya)" (QS. An-Najm: 4).

b. Amanah.
Amanah artinya menyampaikan. Menjalankan bisnis sangat dibutuhkan kepercayaan antara pebisnis dan konsumen untuk menumbuhkan kepercayaan seseorang kepada pelaku bisnis, pebisnis harus bertanggung jawab, memenuhi sesuai dengan ketentuan atau kesepakatan antara pebisnis dengan konsumen tidak mengecewakan atau merugikan salah satu pihak (Aprianto, 2020:12-14). Allah SWT berfirman dalam Surah Al-A'raf ayat 68:

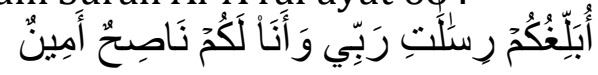

Artinya:"Aku menyampaikan amanat-amanat Tuhanku kepadamu dan aku hanyalah pemberi nasihat yang teroercaya bagimu"(QS. AlA'raaf: 68).

c. Tabligh.

Tabligh artinya menyampaikan. Menjalankan bisnis Islam harus sesuai dengan kondisi barang yang akan dijual tidak menutupnutupi kualitas barang tersebut, kemudian dalam penyampaian ke konsumen harus dengan bahasa yang mudah dipahami dan sopan (Aprianto, 2020:12-14). Allah Swt berfirman dalam Surah Al-Jinn ayat 28:

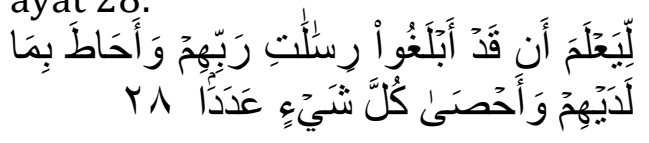

Artinya:" Supaya Dia mengetahui, bahwa sesungguhnya rasul-rasul itu telah menyampaikan risalarisalah Tuhannya, sedang (sebenarnya) ilmu-Nya meliputi apa yang ada pada mereka, dan Dia menghitung segala sesuatu satu persatu."(QS. Al_jin: 28).

d. Fathonah 
Fathonah artinya cerdik atau cerdas. Dalam menjalankan bisnis Islam juga harus cerdas misalnya dalam komunikasi dengan konsumen, mengatur strategi marketing, mempromosikan barang, dan cerdas dalam membaca situasi dalam menjalankan bisnis (Aprianto, 2020:12-14).

\section{METODE PENELITIAN}

Penelitian ini menggunakan metode pendekatan secara kualitatif. Pendekatan kualitatif ini merupakan suatu proses penelitian yang dilakukan dengan mendeskripsikan apa yang ada di dalam lapangan dengan instrumen utama peneliti itu sendiri. Dalam penelitian ini penulis melakukan studi dengan wawancara dan kajian literatur guna untuk memperoleh data yang valid mengenai pedagang musiman di Desa Ngebel yang ditinjau dari perspektif etika bisnis Islam sesuai dengan pokok masalah yang ada.

\section{HASIL DAN PEMBAHASAN}

Berdasarkan observasi dan wawancara kepada para pedagang musiman di daerah Ngebel Ponorogo, sebagian pedagang melakukan persaingan dengan tidak memperhatikan etika bisnis Islam. Alasannya karena banyaknya pesaing pada daerah tersebut serta para pedagang ini hanya menginginkan keuntungan sebanyak-banyaknya untuk keperluan perekonomian tanpa memperhatikan aturan yang telah ditetapkan dalam ajaran agama Islam. Selain itu juga diketahui bahwa banyak pedagang yang menentukan harga barang yang dijualnya terkadang masih tidak sesuai dengan kualitasnya, serta dalam takaran, penimbangan dan ukuran juga masih adanya unsur kecurangan.

\section{SIMPULAN}

Berdasarkan analisis di atas dapat disimpulkan bahwa sebagian pedagang tidak menggunakan etika bisnis Islam karena banyaknya persaingan dan juga untuk tujuan memperoleh keuntungan sebanyak-banyaknya demi kebutuhan perekonomiannya. Diharapkan melalui hasil penelitian ini dapat dijadikan masukan bagi para pedagang musiman untuk menerapkan etika bisnis Islam dalam proses perdagangannya.

\section{DAFTAR RUJUKAN}

Andini dan Aditya. 2002. Kamus Bahasa Indonesia, Surabaya: Prima Media.

Aprianto, Iwan dkk. (2020). Etika \& Konsep Manajemen Bisnis Islam. Sleman: CV. Budi Utama.

Indrajaya, Brian.(2019).Pesaingan Usaha Antar Pedagang Sembako di Pasar Kliwon Karang Lewas, Banyumas Perspektif Etika Bisnis. Skripsi.

Mujahidin, Akmal. (2007). Ekonomi Islam. Jakarta: PT. Raja Grafindo Persada.

Stefhani, Putri Witha. (2019). Persaingan Usaha dalam Perspektif Etika Bisnis Islam Studi Kasus Pedagang Sayur Keliling dan Warung Sayur di Desa Banjarrejo Kecamatan Batanghari Kabupaten Lampung Timur). Skripsi.Metro Lampung: IAIN Metro. 
Sujatmiko, Eko. (2014). Kamus IPS, Surakarta: Aksara Sinergi Media Cet.1.

Susanto dkk. (2019). Persaingan Usaha Tidak Sehat di Indonesia Menurut Hukum Ekonomi Islam dan Undang-Undang Nomor 5 Tahun 1999 Tentang Larangan Monopoli dan Persaingan Usaha Tidak Sehat. Jurnal of Islamic Economics, finance and Banking. Vol.3 No.2.

Undang-Undang No.5 Tahun 1999 Tentang Larangan Monopoli dan Persaingan Usaha Tidak Sehat.

Zamzan, Fakhry dan Havis Aravik. (2020). Etika Bisnis Islam Seni Berbisnis Keberhakahan. Sleman: CV Budi Utama. 